\title{
Artikkeli
}

\section{Töistä kotiin - media kodin ja työpaikan välisen rajanvedon välineenä}

\begin{abstract}
Uusien teknologioiden kyky tuottaa uudenlaisia "siltoja" kodin ja ansiotyön välille on ollut julkisuudessa runsaasti esillä, mutta median rooli rajanvedon välineenä on jäänyt vaille huomiota. Artikkelissa analysoidaan haastatteluaineiston avulla sitä, miten korkeasti koulutetut ja asiantuntijatehtävissä toimivat inmiset kertovat tuottavansa median avulla rajanvetoa ansiotöiden ja vapaa-ajan välille. Tutkimusta varten on haastateltu 39 ihmistä kolmessa eri kaupungissa Suomessa. Jokainen haastateltavista kertoi kotona tehtävien ansiotöiden tai työväsymyksen määrittelevän vapaa-ajan mediavalintojaan. Artikkelissa kiinnostuksen kohteena ovat mediaan liittyvät käytännöt, joiden avulla haastateltavat kertovat ja tulkitsevat tuottavansa vapaa-ajasta ja kotielämästä erilaista työelämään nähden. Mielenkiinnon kohteena on myös se, minkälaisten kielellisten keinojen avulla erilaisille median muodoille tuotetaan omanlaisensa identiteetti niiden toimiessa vapaan ja työn välisen rajanvedon välineinä. Lisäksi artikkelissa analysoidaan minkälaisen subjektiuden haastateltavat tulevat rakentaneeksi itselleen kuvatessaan erilaisia rajanvetoon liittyviä käytäntöjä. Analyysimenetelmänä sovelletaan diskurssianalyysiä. Analyysissä syntyneitä havaintoja syvennetään erityisesti kulutussosiologisen tutkimuksen sekä rajanvetotyön käsitteen avulla.
\end{abstract}

AVAINSANAT: Rajanveto, rituaali, vapaa-aika, kotielämä

$\mathrm{V}$ apaus ja joustavuus ovat teemoja, jotka kytketään julkisuudessa usein etätyöhön. Kotona työskentely esitellään mahdollisuutena saavuttaa uudenlainen henkilökohtainen vapaus. Tieteellisissä puheenvuoroissa ja tutkimuksissa kotona työskentelyn ja vapauden liitto ei näyttäydy yhtä itsestään selvänä. Esimerkiksi Julkusen, Nätin ja Anttilan (2004) tutkimuksen mukaan etätyö käytännössä tarkoittaa sitä, että töitä vain kuljetetaan kotiin ilman erillistä sopimusta. Vain neljä prosenttia Julkusen, Nätin ja Anttilan tutkimista 1653 työssäkävijästä oli tehnyt etätyösopimuksen työnantajansa kanssa. Tästä huolimatta kaksi kolmasosaa oli tehnyt töitä kotona tutkitun viikon aikana. Myös Juha Siltala $(2004,404)$ on huomauttanut, että itsesäätöinen etätyö ei ole lupauksista huolimatta toteutunut, vaan tuoreiden tutkimusten mukaan "töiden kantaminen kotiin on kuitenkin meillä ja muualla ainoa yleistynyt etätyön muoto". 
Uusia teknologioita esitellään ja markkinoidaan meille puhumalla juuri uudenlaisesta joustavuudesta ja vapaudesta, jonka nämä laitteet tarjoavat (Brannen 2005; Punie \& al. 2005: Peteri 2005; Silverstone 1993). Uusien teknologioiden kerrotaan luovan meille mahdollisuuksia muokata ajasta yhä yksilöllisempää. Voimme suorittaa esimerkiksi erilaisia ansiotyötehtäviä ajankohtana, joka sopii juuri meille parhaiten. Näille kertomuksille leimallista on niiden teknologinen determinismi, ajatus siitä, että teknologioilla olisi vääjäämättömiä seurauksia ja vaikutuksia. Uudet teknologiat eivät kuitenkaan vääjäämättä aiheuta ansiotyön valumista kotiin, vaan pikemminkin muutoksen takana on nähtävissä uusi käsitys ansiotyöstä ja etätyöskentelyn luonnollisuudesta. (Silverstone 1993.) Uudet teknologiat voivat toimia erilaisten arkielämän sfäärien (kuten ansiotyö ja vapaa-aika) rajojen rikkojina, mutta samaan aikaan myös rajojen säilyttäjinä ja turvaajina (Silverstone 2005, 15).

Artikkelissa analysoin miten inmiset kuvailevat tuottavansa erilaisten median muotojen avulla rajanvetoa ansiotöiden ja vapaa-ajan välille tilanteessa, jossa he joko kertovat tekevänsä ansiotöihin liittyviä tehtäviä kotona tai kertovat työväsymyksen määrittelevän vapaa-ajan mediavalintojaan. Olen erityisen kiinnostunut siitä, minkälaisien mediaan liittyvien käytäntöjen avulla haastateltavat kuvaavat tuottavansa vapaa-ajasta ja kotielämästä erilaista työelämään nähden sekä niistä kielellisistä keinoista, joiden avulla media tuotetaan asiana, joka toimii siirtymäriitin välineenä tai selviytymisstrategiana työn ja vapaa-ajan välisistä suhteista neuvoteltaessa. Tarkastelen artikkelin lopussa myös sitä, minkälaisen subjektiuden haastateltavat tulevat rakentaneeksi itselleen kuvatessaan erilaisia rajanvetoon liittyviä käytäntöjä.

Artikkelin aineiston muodostavat kuudentoista perheen haastattelut, joihin osallistui yhteensä 39 henkilöä. Haastattelut on tehty pääkaupunkiseudulla, Tampereella ja Rovaniemellä kesän 2006 aikana. Perheet muodostuivat korkeasti koulutetuista vanhemmista ja heidän lapsistaan mutta mukana oli myös kahden aikuisen talouksia, joilla joko ei ollut lapsia tai lapset olivat jo muuttaneet pois kotoa. Haastateltavien joukossa oli muun muassa lääkäreitä, johtajia, opettajia, yksityisyrittäjiä, tutkijoita sekä kotiäiti ja opiskelija. Haastateltavia voi kuluttajina luonnehtia keskiluokkaisiksi, sillä vaikka heillä onkin taloudellisia resursseja ostaa tuotteita ja palveluja, he joutuvat kuitenkin pohtimaan suurempien hankintojen kohdalla mitä hankitaan ja milloin. (ks. Katz-Kerro 2002).

Analyysimenetelmänä sovelletaan diskurssianalyysiä. Diskurssianalyysi korostaa puheen tutkimista nimenomaan tilanteisena toimintana (Saarenheimo 1997, 31), joka on itsessään läpeensä sosiaalista. Ihmiset tekevät asioita puheellaan: he voivat oikeuttaa, vakuuttaa, syytellä, suostutella ja kysyä. (Potter \& Wetherell 1989, 32; Suoninen 1992, 20; Wetherell \& Maybin 1996, 265.) Oikeuttamisen analysointi viittaa myös siihen, miten ihmiset pyrkivät tuottamaan itsestään ja toimistaan moraalisesti oikeutettua kuvaa. Ihmiset valitsevat erilaisten kielellisten keinojen välillä, he ovat "toimijoita moraalisessa universumissa", jossa pyrkivät neuvottelemaan itselleen uskottavasti ja vakuuttavasti kompetentin toimijan position (Burr 1995, 120).

Kompetentin toimijan position neuvotteleminen näkyy erityisen selkeästi siinä, miten haastateltavat aineistossa irtisanoutuvat ajatuksesta, että uupumus työtehtävistä johdattaisi heidät vain "helppojen" ja vähemmän kehittävien mediasisältöjen 
äärelle. Yksi tapa tuottaa itsestään ja toiminnastaan moraalisesti hyväksyttävämpää on omaksua ulkopuolisen arvioijan positio, josta käsin osoitamme tiedostavamme, että emme toimi täysin oikein. Kun osaamme itse kritisoida omaa toimintaamme, osoitamme olevamme rationaalisia, itsearviointiin kykeneviä ja siten hiukan paradoksaalisesti vähemmän moraalisesti epäilyttäviä. (Eyre, Davis \& Peacock 2001, 2-3; 12; Jolanki 2004, 500.)

Kiinnittäessäni huomiota siihen, mitä haastatteluissa sanotaan, analysoin diskurssianalyysille ominaisella tavalla myös sitä, mitä jonkin sanomisella tuotetaan, minkälaisia merkityksiä itse vuorovaikutuksessa rakentuu. Työelämän ja vapaa-ajan rajaa tuotetaan osaltaan myös seuraamalla median muotoja ja kertomalla omasta median käytöstä. Vapaa-ajan ja ansiotyötehtävien raja rakentuu myös niissä arkisissa tavoissa, joilla merkityksellistämme median käyttöämme kotona ja niillä kielellisillä keinoilla, joilla kerromme näistä tottumuksistamme ja mieltymyksistämme.

Näkökulman mukaisesti työn ja kodin rajanvetoa tehdään vuorovaikutuksessa ja työn ja kodin raja on tietyssä sosiaalisessa tilanteessa syntynyt saavutus, ei siis jotain valmiina olemassa olevaa. Artikkelissa hyödynnetään diskurssianalyysin muotoa, joka on kiinnostunut tunnistamaan millä keinoilla "todellisuutta, yhteiskuntaa, tapahtumia ja sisäisiä psykologisia tiloja tuotetaan puheessa" (Potter 2004, 202). Näkökulma edellyttää asenteena jonkinlaisen antropologisen vierauden omaksumista: on osattava kysyä, mitä on asia, jota kutsutaan "mediaksi", silloin kun sen ihmisten kuvauksissa tulkitaan toimivan resurssina työn ja vapaa-ajan eron teolle. Minkälainen on kuvailuissa se tilanne, konteksti, jossa media toimii vapaa-ajan ja ansiotyön eron tekijänä? Käytännössä tämä tarkoittaa myös sellaisten analyyttisten kysymysten esittämistä aineistolle kuin millä konkreettisilla kertomisen keinoilla tuotetaan ihmisten kuvauksissa tietyn median muodon erityinen rooli työstä vapaalle siirryttäessä.

Diskurssianalyysin hengessä tutkimusyksikkönä eivät toimi yksittäiset yksilöt tai perheet, vaan aineistokatkelmat. Aineistona artikkelissa on siis hyödynnetty niitä aineistokatkelmia, joissa haastateltavat puhuvat median käytöstään siten, että se kytketään tavalla tai toisella puheeseen työelämän ja vapaa-ajan välisistä suhteista.

Diskurssianalyysin avulla artikkelissa pureudutaan puheen piirteiden tunnistamiseen ja siihen, minkälaisena syntyy identiteetiltään asia, jota kutsutaan "mediaksi" haastateltavien kuvailuissa, silloin kun he pohtivat ansiotyön ja vapaa-ajan suhteita. Tämän jälkeen diskurssianalyysin avulla tuotetut havainnot ja oivallukset asetetaan uuteen kontekstiin ja niille luodaan uusia merkityksiä hyödyntämällä tulkintateoreettisina ja käsitteellisinä välineinä kulutuksen sosiologisia tutkimuksia sekä työn ja vapaaajan rajanvetotyöskentelyä analysoivaa tutkimuskirjallisuutta. Tulkintateoriat siirtävät diskurssianalyyttisesti tuotetut havainnot toiselle abstraktiotasolle, toisenlaiseen todellisuuteen (Ronkainen 2004, 65-66).

\section{Aito ja vapaa kotielämä luomuksena}

Ennen teollista vallankumousta erottelu työpaikan ja kodin välillä olisi ollut absurdi, sillä suurin osa työstä tehtiin kotona. Teollistumisen myötä palkkatyö alkoi eriytyä 
kotona tehtävästä muusta työstä eli ns. kotityöstä. (Berke 2003, 513; Salmi 1991, 50.) Näkemys, jonka mukaan ansiotyö ei kuulu kotiin, on siis historiallisesti varsin tuore ja tässä valossa sitä voisi pitää jopa erikoisena (Julkunen, Nätti \& Anttila 2004, 160). Uusien teknologioiden kehittyessä on alettu pohtia ansiotöiden mahdollista siirtymistä yhä enenevässä määrin takaisin kotiin. Työstä onkin alettu puhua jopa "mielentilana" (Kivimäki 1999, 150) ja on esitetty arveluja, että kodista olisi uudella tavalla tulossa myös kouluttautumisen paikka, viihdekeskus ja ansiotyöpaikka. (Kumar 1997, 214-215.)

Artikkelissa työelämää ja vapaa-aikaa ei tarkastella toisistaan selkeästi erillisinä tilallisina ja ajallisina sfääreinä. Kun ansiotyötä ja vapaa-aikaa ei tarkastella vakiintuneina, selkeän erillisinä alueina, vaan toisiaan monin tavoin läpäisevinä, on tarpeellista ja tärkeää pohtia sitä, miten yksilöt arjessa tulkitsevat, tuottavat ja pitävät yllä rajoja näiden elämänalueiden välillä.

Moderni vapaa-aika ja kotielämä tarkoittavat käytännössä nykyisin aikaa, jota vietetään erilaisten median muotojen äärellä (Livingstone 2002, 167-168) ja siten voi perustellusti olettaa, että medialla on oma merkityksellinen roolinsa siinä, miten rajoja eri elämänalueiden välillä neuvotellaan.

Nykyään kodin ajatellaan pitkälti olevan synonyymi perhe-elämälle. Perheen ja kodin samastamisen juuret ovat työpaikan ja kodin eriytymisessä sekä kehityksessä, jonka myötä lapsuus alettiin hahmottaa uudella tavalla. (Rybczynski 1986, 39, 77.) Kun moderniin perhekäsitykseen kuuluu ajatus siitä, että perhe-elämä vaatii oman "puhtaan ajan ja tilan", kytkeytyy tähän samalla uudenlainen ajatus perhe- ja parisuhteista myös työtä vaativina projekteina. (Julkunen, Nätti \& Anttila 2004, 160.) Ansiotöiden ja vapaa-ajan rajan ylläpitäminen vaatii siis uudenlaista työskentelyä. Rajojen ylläpitäminen on keskeistä toimintaa, jolla arjessa uusinnamme kokemusta oikeanlaisesta kodista ja kotielämästä. Eletty kokemus joidenkin asioiden kotoisuudesta vaatii meiltä erilaisten rajojen valvomista ja säilyttämistä. Kotoisuus ei ole valmiina, vaan se vaatii tuottamista ja vaalimista. (Moores 1996, 48.)

Teollistunut yhteiskunta on edellyttänyt yksilöiltä uudenlaista subjektiutta. Yksilöiden on kyettävä yhä paremmin hallitsemaan tunteitaan ja sisäistämään kontrolli. Niinpä kotielämän on ajateltu edustavan paikkaa, jossa tunteita voidaan vapaasti elää ja kokea. (McDowell 1999, 75.) Koti- ja perhe-elämän "puhtauden" ylläpitäminen vaatii kuitenkin rajanvetotyöskentelyä (engl. "boundary work", ks. esim. Ashforth, Kreiner \& Fugate 2000; Desrochers, Hilton \& Larwood 2005; Nippert-Eng 1996), jonka, kuten englanninkielinen termi kuvaa, voi ajatella rinnastuvan työn tekemiseen. Rajanvetotyö viittaa niihin "strategioihin, periaatteisiin ja käytäntöihin, joiden avulla tuotamme, uusinnamme ja muunnamme kulttuurisia kategorioita" (Nippert-Eng 1996, 7).

Vapaa-ajan ja työelämän rajanveto siis paradoksaalisesti tuottaa kodista ja vapaaajasta sfäärin, jonka ylläpidon voi ajatella vaativan uudenlaista "projektityöskentelyä". Tämän työskentelyn tulee kuitenkin erota laadullisesti siitä työn tekemisestä, joka liittyy ansiotyön tekemiseen. Muussa tapauksessa rajanvetotyöskentely hämärtäisi jo itsessään sitä rajaa, jota sen päämääränä on ylläpitää. 


\section{Media siirtymäriittien resurssina}

Christena Nippert-Eng kirjoittaa kirjassaan Home and Work (1996) siitä, miten inmiset käytännön toiminnassaan aktiivisesti tuottavat rajaa ansiotyön ja kotielämän välille. Nippert-Eng osoittaa, miten hyvin arkiselta tuntuvat valinnat ovat osa toimintaa, jolla tuotamme ja pidämme yllä järjestystä eri elämänalueiden välillä. Konkreettisia kysymyksiä, joiden avulla Nippert-Eng analysoi työ- ja kotielämän sfäärien välistä suhdetta, olivat muun muassa: onko meillä rakkaittemme kuvia työpaikalla, ovatko työavaimemme samassa ketjussa kotiavainten kanssa, pukeudummeko samalla tavalla kotona ja työpaikalla, puhummeko samalla tavalla töissä kuin kotona, olemmeko vapaa-ajalla tekemisissä työtovereiden kanssa ja onko meillä esimerkiksi erilliset kalenterit vapaa-aikaa ja työaikaa varten. Lähestymistapa nostaa esiin, kuinka erilaisia artefakteja hyödynnetään joko rajan tai sillan rakentamisessa. Uusien teknologioiden kyky tuottaa uudenlaisia "siltoja" kodin ja ansiotyön välille on ollut julkisuudessa runsaasti esillä. Median rooli rajanvedon välineenä on jäänyt vähemmälle huomiolle.

Yksi tapa tuottaa rajanvetoa on hyödyntää mediaa selkeän siirtymäriitin välineenä. Van Gennep (1960) määrittelee siirtymäriitin rituaaliksi tai seremoniaksi, joka helpottaa yhdestä roolista toiseen siirtymistä. Siirtymäriitti ilmaisee niin riitin suorittajalle kuin muillekin, että siirtymä roolista toiseen on käsillä. Siirtymäriitin käsitettä on hyödynnetty analysoitaessa yhteisöissä laajemmin tunnistettuja roolisiirtymiä (kuten rippikoulun käyminen tai ylennyksen saaminen), mutta riitin käsite on sovellettavissa myös ns. mikrotason siirtymiin, jotka voivat olla väliaikaisia, mutta toistuvia roolin vaihdoksia (Ashforth, Kreiner \& Fugate 2000,478 ). Kaikilla riiteillä voi nähdä olevan rooli siirtymän tuottajana yhdestä sosiaalisesta roolista toiseen.

Aineistossa on runsaasti kuvauksia, joissa median kerrotaan toimivan resurssina selkeälle siirtymälle. Keski-ikäinen nainen kuvailee, miten sanomalehden lukeminen liittyy hänellä töistä kotiin palaamiseen:

Se on ehdottomasti se hetki jota mä odotan, niin et mä otan ensin kahvit ja voileivät ja sit se lehti ja se on siis ihana hetki aina et siinä, tavallaan latautuu taas uuteen rooliin ja siihen, pääsee pois siitä työkuviosta. (Haastattelu V6: Opettajaäiti ja tytär)

Haastateltava kertoo myöhemmin, että hän ei halua lukea lehteä ennen töihin menoa, koska hän on kiireinen ja koska "monet uutiset on niin negatiivisia eli mä en halua latautua sillä lailla". Sanomalehti, joka aamulla veisi liikaa aikaa ja lataisi kertojan negatiivisilla uutisilla onkin iltapäivällä asia, jonka ympärille rakennetaan seesteiseltä vaikuttava, "ihana hetki" voileipineen. Viikonloppuisin sanomalehti luetaan perheessä jo aamulla ja siihen käytetään haastateltavan mukaan useita tunteja. Haastattelussa sanomalehden lukeminen piirtyy siirtymäriittinä, jonka avulla kertoja astuu työroolista vapaa-ajan ja perheen edellyttämään rooliin. Siirtymäriitin hengen sanomalehden lukeminen töiden jälkeen ja viikonloppuna saa siitä, miten haastateltava tulee kuvailleeksi valmistelutyötä, joka lukuhetkeen liittyy ja sitä, miten tämän odotetun hetken aikana "latautuu uuteen rooliin". Lukemisen intensiivistä merkitystä korostaa myös se, että haastateltava kertoo, miten viikonloppuna saattaa kulua kolmekin tuntia aamun lehden lukemiseen. 
Useassa haastattelussa tähdennettiin, että viikonlopusta erityisen tekee se, että perhe tai pariskunta varaa runsaasti aikaa yhteisen aterian valmistamiseen, kattaukseen ja syömiseen. Aterian valmistamiseen saattoi liittyä pitkin arkiviikkoa erityistä valmistelutyötä, johon hyödynnettiin useita median muotoja. Esimerkiksi eräs vanhempi pariskunta kertoi etsivänsä aktiivisesti ruokailuun liittyviä ideoita television ruokaohjelmista, kirjoista, aikakauslehdistä ja internetistä. Viikonlopun erityisten hetkien valmisteluun saatettiin siis käyttää useita erilaisia median muotoja ja kärjistetysti tätä valmistelutyötä voisi jo kutsua "projektinomaiseksi" työskentelyksi. Vaatiiko projektityö siis vastapainokseen erityistä projektinomaista vapaa-aikaa?

Kulutushistorioitsija Colin Campbellin (2005) mukaan keskiluokka on viime vuosina kohdannut uudenlaisia työelämän haasteita. Lisääntynyt byrokratia ja erilaiset työn laadun varmistuksen strategiat ja arvioinnit ovat heijastuneet myös vapaa-ajalle. Kotielämä on latautunut uudenlaisilla odotuksilla ja työprojektien lisäksi ihmisten on nyt suoriuduttava myös vapaa-ajasta erityisenä elämänprojektina, jonka toivotaan tarjoavan tunnetta autenttisesta itsensä toteuttamisesta. Vapaa-ajan toiminnasta pyritään aktiivisesti tuottamaan merkityksellisempää.

Campbellin ajatuksia seuraten voi ajatella, että jos ennen laitettiin ruokaa, nyt harrastetaan ruokakulttuuria, kun ennen seurattiin lauantai-illan dekkareita saunan jälkeen, nyt voidaan valita dvd-boxi ja seurata kokonainen tuotantokausi ja kun aiemmin siivottiin, nyt harrastetaan sisustamista ja kodin laittamista. Jopa aiemmin välttämättömiä kodin rutiineja voidaan kytkeä osaksi perheen yhteisiä tai yksityisiä harrastuksia. Näin kotielämän ja vapaa-ajan merkitystä voidaan korostaa, tehdä rutiineista harrastuksia ja siten ylevöittää ne (aiheesta Luomanen 2010).

Haastatelluista perheistä useampi toi myös esille, että viikonlopun aterian jälkeen oli saatettu varata dvd-elokuva, joka katsottiin yhdessä. Arkinen televisionkatselu saattoi kertomusten mukaan käytännössä usein tapahtua eri huoneissa, joissa perheenjäsenet seurasivat ohjelmia omien mieltymystensä mukaisesti. Viikonlopulle keskittyi kuvausten mukaan enemmän nimenomaan yhteistä television ja elokuvien katselua. Keskeinen ero verrattaessa kertomuksia viikonlopun ja arkiviikon televisionkatselusta on se, että viikonlopun katselun tähdennettiin tapahtuvan tietoisen ja tarkemman valinnan kautta: joko käytiin varta vasten ostamassa tai lainaamassa jokin tietty dvd-elokuva tai valikoitiin tarkkaan, mitä televisiosta katsottiin. Viikonloppuna seuratusta ohjelmasta voitiin mainita erityisiä syitä sen valintaan (ohjaaja, elokuvan genre tai vaikkapa historiallinen aika, jota siinä kuvattiin tms.). Käytännössä ihmiset voivat yhä toteuttaa viikonloppuisin aivan samoja mediasisältöjen valintoja kuin muulloinkin. Tällä tutkimusotteella en voi väittää mitään siitä, mitä inmiset todella tekevät. Diskurssianalyyttisesti on kuitenkin kiinnostavaa se, että viikonlopun television katselu täytyy kehystää kuvauksilla, jotka tuottavat siitä toimintana tietoisempaa ja valikoivampaa.

Etenkin kirjojen lukemisen ja television katselun kautta kuvauksissa jäsennetään yhä myös juhla-aikojen ja lomien erityisyyttä. Kesäaikaan ja joululomalla kuuluu selvästikin yhä lukea enemmän. Television katselun kerrotaan asettuvan sekundaarisempaan asemaan kesä- ja loma-aikaan. Mökillä mainitaan kuunneltavan radiota, vaikka siellä olisi myös televisio. Kuvauksissa maininnat kesäajan lukemisesta kytkeytyvät herkästi kertomuksiin, joissa viitataan nuoruuden tai lapsuuden aikaisiin kokemuksiin 
ja luodaan niihin jatkumo: "sit heti kun tuli kesä niin mä luin öitä myöten sitten mökillä vintillä". Jatkumon kuvaaminen toimii keinona, joka vahvistaa vaikutelmaa toiminnan aidosta ja pitkäaikaisesta merkityksestä.

Kun printtimedia toimii siirtymäriittinä, keskeistä kuvauksissa on kontekstin tarkka kuvaaminen. Hetken merkityksellisyys rakennetaan siten, että juuri lukemisen konteksti kuvataan tarkemmin kuin esimerkiksi arkisen television katselun tai tietokoneen käytön konteksti. Lukemiskontekstin kuvauksessa tullaan maininneeksi mitä syödään tai juodaan, kun luetaan. Merkityksellisenä kontekstin piirteenä voidaan tuoda esille myös tilanteeseen pukeutuminen; villasukat, lempipaita ja kaikista pehmeimmät pyjamahousut. Voidaan myös mainita minkälaisella istuimella tai makuualustalla kertoja lukee tai kuvailla muita ympäristön piirteitä kuten takkatulen ääntä tai tuulen viuhuntaa ulkona. Näin kuulijalle rakennetaan kuva lukemishetken intensiivisyydestä ja erityislaatuisesta merkityksestä. Siirtymäriitin hengen mukaisesti viikonlopun media näyttäytyy erityisenä, valmistelutyötä vaativana "projektina". Viikonlopun television katselu tuotetaan arkiseen katseluun verrattuna valikoivampana ja tietoisia valintoja edellyttävänä prosessina.

\section{Media selviytymisstrategiana}

Lukemiskontekstista tuotetaan aineistossa siis yksityiskohtaisia kuvauksia, joiden avulla lukemisen merkityksellisyys tulee tähdennettyä. Arkiviikon aikana tapahtuvaan television katseluun ei liity tällaisia kuvauksia, vaan sen sijaan niihin liittyy mielentilaa luonnehtivia selostuksia, joiden avulla television katselu tuotetaan luontevana vaihtoehtona. Lukeminen voi tuottaa tietynlaisen mielentilan ("kirja vie sut totaalisen toiseen maailmaan et sä lähdet sillon sille seikkailulle ja sä lähet pois tästä maailmasta") mutta television katselu jäsennetään asiana, joka liittyy ja sopii tiettyyn mielentilaan, jota voidaan kuvailla, mutta se ei sinänsä johdata kyseisestä mielentilasta samalla tavalla pois:

Joskus jos on henkisesti laiskassa tilassa ja jättäny ton pöntön päälle ja sielt tulee mitä sattuu, niin sit sitä jotenkin hermostuu itseensä että, että miksi kävelen täälä huonees edestakasin, vilkuilee, miksei ota just jotain kirjaa tai lehtee ja mene jonnekin istuskelemaan kaikessa rauhassa, nyt ois se hetki. Televisio on semmonen kun on levoton ja vähän stressaantunu niin, se sitten se suorastaan sopii siihen olotilaan että vaikkei sitä seuraakaan. (Haastattelu V2: Konsulttinainen, varhaiseläkkeellä oleva mies ja tytär)

Katkelman keski-ikäinen naiskertoja kuvailee, miten hän kokee levottoman työväsymyksen tilassa, että nyt olisi hetki mennä lukemaan kirjaa tai lehteä kaikessa rauhassa. Sen sijaan hän jää enemmän tai vähemmän passiivisesti seuraamaan televisiota, koska "se suorastaan sopii siihen mielentilaan". Kertoja tuottaa television vähän arvostettavana asiana, sillä hän puhuu pöntöstä, jonka on henkisen laiskuuden vuoksi jättänyt päälle. Huomioitavaa on, että hän kuitenkin ilmaisee tietävänsä, että television ääreen jääminen ei ole ideaali ratkaisu. Osoittamalla tietoisuutensa tästä, hän ikään kuin asettuu itsensä ulkopuolelle ja oikeuttaa arviollaan vähemmän hyväksytyn valinnan. Hän 
kuitenkin tiedostaa ja osaa arvioida toimintaansa, jolloin television ääreen jääminen on myös oma valinta, ei vain passiivista seuraamista. Samantapaisesti toinen keskiikäinen naiskertoja kuvailee oivaltavansa, että lukeminen voisi rentouttaa paremmin, mutta television katselu palvelee kuitenkin toisella tavalla:

Nainen: Mä lähden ihan oikeesti jonnekin muualle [lukiessa] et televisioo katsoessa mä oon kuitenkin tässä, mä voin samalla huudella et tehkää sitä tai tätä ja tollain noin. Haastattelija: Niin justiin, mennä jääkaapille ja kaikkee tällasta näin.

Nainen: Niin joo, joo. Ja erityisesti jos sä seuraat näitä missä on mainoskatkot niin eihän se oo mitään, et se on oikeestaan aika, mutta televisio liittyy ihan tähän meiän maailmaan, tähän kiireiseen maailmaan et se sopii tähän kiireiseen maailmaan. Et eihän se sillä lailla, totta kai jos sä katsot, jonkun upean elokuva niin se vie sut pois. (Haastattelu V6: Opettaja-äiti ja tytär)

Edellisille kuvauksille television katselemisesta yhteistä on se, että televisio-ohjelmien seuraaminen ei samalla tavalla määrity selkeänä siirtymärituaalina työn sfääristä kodin sfääriin, vaan enemmänkin selviytymisstrategiana, jonka avulla kiireisyyden ja väsymyksen tilassa televisio tunnistetaan kyseiseen tilaan sopivaksi ja sitä helpottavaksi median muodoksi. Vaativa työ kuitenkin oikeuttaa katselun, sillä televisio-ohjelman voi ajatella palvelevan siitä palautumista.

Kirjoihin ja lehtiin liitetyt kuvaukset mielentilan muutoksesta ovat tulkittavissa siirtymiksi roolista tai positiosta toiseen. Kirja ja lehdet jäsennetään toistuvasti kuvauksissa siirtymien tuottajina. Siirtymä voi myös merkitä valveesta uneen siirtymistä, kuten 30-vuotiaalla toimistotyöläisellä, joka kertoi että "musta tuntuu, että mä en oikeestaan pysty rentoutumaan jos en mä lue" ja jatkoi hieman myöhemmin haastattelussa, ettei "oikeen pysty nukahtaan ilman että mä ainakin vähän aikaa pidän sitä kirjaa kädessä". Kirja toimii tässä esineenä, joka johdattaa rauhalliseen mielentilaanja mahdollistaa jopa nukahtamisen. Kertojan kumppani lisääkin hiukan sarkastisesti, että hänen tehtävänsä on noukkia kirja nukahtaneen takapuolen alta, kun "se on siellä myllänny ja pyöriny koko yön". Kumppani jatkaa kertomalla omasta työputken jälkeisestä rentoutumisprojektistaan:

Mies: Mulla se varmaan tulee, kyllä mä kärsin siitä että mä teen silleen projektiluontosesti töitä itte. Että mä innostun jostain työjutusta ja sitten mä sitä teen. Kunnes mä en pysty enää keskittymään mihkään. Ja sitten mä oon nyt vasta oppinu sen, et mä joudun lepuuttaa. Ja monesti mulla käy esimerkiks niin että mä sitten vuokraan, haen kirjastosta Raidin ja pusken putkeen sen 12 tuntia Raidia tai katon jonku Taistelutoverit DVD-setin kahessa päivässä. Tai siis jotain aivan älytöntä. Nainen: Niin semmonen ihan, kalsareissa keskellä päivää.

Mies: Sit tavallaan tää viikko Uunojen parissa on palkinto, että nyt on tehty pirusti töitä. Et nyt katotaan Raidi tänään, tänään alotan ja huomenna lopetan. Et siihen liittyy tää tämmönen. Et samalla kun se on selkeesti tämmönen, herää siihen että on liian väsyny. Ni se on palkinto myös siitä, et on tehty jotain. (Haastattelu V9: Tutkijanainen ja tutkijamies) 
Media palkitsemisen muotona voi toimia kuvauksissa resurssina siirtymälle, joka merkitsee laajamittaisen työprojektin päättymistä, sekä selviytymisstrategiana, kuten edellisessä noin 30-vuotiaan miehen kuvauksessa pitkästä työputkesta, jonka päätökseksi hän varaa töiden jälkeisille illoille aikaa "nollaukselle", joka tapahtuu seuraamalla intensiivisesti pitemmän ajan tietyn tyyppisiä elokuvia tai tv-sarjoja.

Vaikka edellisessä katkelmassa on kyse eräänlaisesta siirtymästä, kuvauksessa ei ole sellaista siirtymäriitin "juhlallista" henkeä, jossa korostuisi toiminnan keskittyneisyys ja sen arvokkuus toimijalle. Pikemminkin siirtymä muistuttaa klassista "kalsarikänniä", viikonlopun kossupulloa, jonka avulla rentoudutaan työviikon paineista. Toisaalla haastattelussa mieskertoja myös tarkentaa, että tv-sarjat ja elokuvat, joita hän seuraa tällä tavoin, ovat yleensä aina samoja. Kyse on toistoseuraamisesta, jossa keskeistä on, että sisällöt eivät ole "kehittäviä", vaan tuttuja ja ei-yllätyksellisiä.

Kertoja mainitsee kärsivänsä työn projektiluontoisuudesta. Kiinnostavasti hän kuvaa eräänlaisen oppimisprosessin, jonka seurauksena hän on ymmärtänyt, että projektityössä tulee tietty piste, jonka jälkeen hän ei pysty enää keskittymään mihinkään, vaan joutuu lepuuttamaan itseään. Projektityö vaatii siis itseään tarkkailevan minän; on kyettävä näkemään milloin on pysäytettävä työtä tekevä minä ja luotava aikaa "nollaukselle".

\section{Itseään tarkkaileva ja palkitseva minä}

Protestanttisen etiikan hengen väitetään tuottaneen subjektin, jolle moraalisen, sosiaalisen ja henkilökohtaisen hyvän elämän ytimen muodosti ahkera työnteko. Modernimman työntekijän edellytetään olevan paitsi ahkera työntekijä osana tuotantoprosessia myös toisenlainen talouden toimija eli kuluttaja, joka tuottaa kulutusvalinnoillaan elämään merkityksellisyyttä ja hyvää elämänlaatua. Moderni elämänlaatu ei ole irrallaan ansiotyöstä, sillä hyvän elämän yksi tekijä on ansiotyö, jonka ajatellaan voivan tarjota kokemuksia itsensä toteuttamisesta ja merkityksellisyydestä. (Rose 1999, 103-104.) Vapaa-ajalla koetun ja tuotetun hyvän elämänlaadun ajatellaan myös heijastuvan yksilön työsuoritukseen. Näin vapaa-ajalla tapahtuva merkityksellinen kuluttaminen palvelee käänteisesti myös työelämää, sillä elävöitynyt ja rentoutunut työntekijä antaa laadukkaamman panoksen työnantajalleen.

Modernilta työntekijältä, ja yksilöltä yleisemminkin, edellytetään vastuullista subjektiutta. Modernit vallan muodot ovat vastuullistaneet subjektin siten, että hän omaksuu itseään tarkkailevan ja kontrolloivan position. Hän oppii sekä sisäistämään asiaankuuluvat käyttäytymistavat että haluamaan "vapaasti" juuri sitä, mitä häneltä edellytetään. Häntä ei tarvitse pakottaa tai vahvasti ohjata, sillä hän on oppinut haluamaan sitä, mitä hallintakoneisto hänen toivookin tekevän. (Sending \& Neumann 2006.) Ihmiset esimerkiksi "haluavat" tehdä ansiotöitä kotona, koska sen ajatellaan tarjoavan heille kilpailuedun suhteessa työtovereihin. Kun yhä useampi ajattelee samalla tavalla, kotona työskentelystä muodostuukin vähitellen yleinen käytäntö ja pakko, jota ilman ei työelämässä voi selvitä. (Siltala 2004.) 
Vapaa-ajan merkityksen intensivoitumisen kanssa samanaikaisesti kokemus lisääntyneistä ajan käyttöön liittyvistä paineista on ainakin länsimaissa yleisesti jaettu (Kaufman-Scarborough 2006, 66; Parkins 2004, 364; Southerton \& Tomlinson 2005; Sullivan 2008). Kyseinen kokemus on koskettanut erityisesti korkeasti koulutettua keskiluokkaa, joka toimii asiantuntijatehtävissä. Julia Brannen (2005) tunnistaa kehityssuuntauksen, jossa lisääntynyt työpaine näkyy erityisesti niiden elämässä, jotka toimivat työtehtävissä, joille leimallista ovat itsenäisyys ja oma päätösvalta työtehtävien strukturoinnin suhteen. Paradoksaalisesti siis ne, jotka omaavat eniten päätösvaltaa oman työnsä organisoinnin suhteen, tekevät pisimpiä työpäiviä ansiotyötehtävien ääressä niin töissä kuin kotona.

Kun haastateltavat aineistossa kuvailivat tilanteita, joissa he tekivät ansiotyötehtäviä kotona, he tuottivat itselleen subjektiuden, jossa korostettiin nimenomaan omaa kontrollia ja vapautta työn tekemisen käytäntöjen suhteen. Työnantajan asettamista reunaehdoista tuotettiin mainintoja ja näiden mainintojen voi ajatella horjuttavan kuvaa työntekijän omasta kontrollista. Haastatteluissa mainittiin, että kotona oleva internetyhteys oli työnantajan maksama, mikä sisälsi jo odotuksen ja oletuksen kotona työskentelystä. Jotkut kertoivat, että heillä oli vapaa-ajallakin työnantajan matkapuhelinliittymä ja että työpuheluita saattoi joskus tulla iltaisin ja viikonloppuisin. Näiden reunaehtojen sisällä haastateltavat kuitenkin toistuvasti tähdensivät itsetarkkailua ja itsekontrollia kotona työskentelyä kuvatessaan. Seuraavassa katkelmassa keski-ikäinen nainen tähdentää omaa päätösvaltaansa:

Sit ku mä teen joskus viikonloppusin töitä mut se on semmonen etukäteen tehty valinta. Tänä viikonloppuna mä teen mutta muuten ei oo se, ja sit se et kun on mökillä niin se korostuu entisestään, sen takii varmaan on niin tärkeetä et saa vaihtaa ympäristöö. Se on ihan kun ois pitemmällä lomalla kun on muualla, kyl se sillon on helppoo. (Haastattelu V2: Konsulttinainen, varhaiseläkkeellä oleva mies ja tytär)

Kotona työskentelyn tavallaan oikeuttaa se, että kertoja mainitsee työn tekemisen olevan etukäteen tehty valinta. Hän ei siis kuvauksessaan ajopuumaisesti ajaudu tekemään töitä, vaan tilannekohtaisesti valitsee tehdä niin. Tämän voi ajatella kerronnallisena strategiana, jolla paitsi oikeutetaan kotona työskentely, myös tuotetaan itsestä vapaa ja omaehtoisia valintoja tekevä asiantuntijatoimija. Realistisesta näkökulmasta ajateltuna on varmasti myös helpompi tehdä vapaa-ajalla töitä, jos voi ajatella tekevänsä niitä omasta valinnastaan. Kun kertoja haluaa selkeää vapaa-aikaa, hänen on lähdettävä perheineen mökille, jolloin ympäristön vaihtaminen tuottaa intensiivisemmin kokemuksen lomalla olemisesta.

Edellisen haastateltavan puhetavan voi ajatella johtuvan haastattelijan esittämistä kysymyksistä ja haastattelutilanteesta. Tietyssä mielessä näin onkin mutta diskurssianalyyttisestä näkökulmasta tämä ei tyhjennä analyysin merkitystä, sillä ihmiset soveltavat haastattelutilanteessa puhetapoja ja puheen keinoja, jotka ovat kulttuurissamme mahdollisia. Ihmiset eivät siis keksi puhetapoja tyhjästä. Tutkimushaastattelu on yksi keskustelun tyyppi, ja sitä on mielekästä ajatella Pirjo Nikanderin tavoin vuorovaikutuksena, joka ei ole irrallaan tai täysin itsenäistä muusta haastattelun ulkopuolella 
tapahtuvasta vuorovaikutuksesta. Mikäli tietyt piirteet haastatteluvuorovaikutuksessa toistuvat, voimme hyvällä syyllä olettaa, että kyseinen ilmiö ei rajoitu vain haastattelutilanteisiin. (Nikander 2002, 20-23.)

Useampi haastateltava mainitsi jättävänsä joko töissä käyttämänsä kannettavan tietokoneen työpaikalle tai tekevänsä kotona mieluiten sellaisia työtehtäviä, joihin ei liittynyt tietokonetta. Jopa tietokoneeseen liittyviä vapaa-ajanaktiviteetteja kerrottiin tietoisesti vältettävän:

Siis töissä oon naimisissa sen koneen kanssa, siis mä en halua koskee siihen kotona ollenkaan. Se on tietoinen valinta et mä en, vaik manuaalista puhelinluetteloa mielummin kuin käyn hakemas sielt yhtään mitään, että jotenkin sitä on niin paljon töissä tietokoneen kans tekemisissä. (V3: Yksityisyrittäjämies ja yksityisyrittäjänainen)

Katkelmassa haastateltava kertoo, että ei käytä tietokonetta kotona ollenkaan ja mainitsee vielä, että kyseessä on "tietoinen valinta". Haastateltava luonnehtii työpäivien suhdetta tietokoneeseen perhe-elämään liittyvällä analogialla: "töissä oon naimisissa sen koneen kanssa", jonka voi ajatella oikeuttavan ja selittävän sen, että perheellisenä henkilönä hän ei vapaa-ajallaan halua koskeakaan tietokoneeseen ja haluaa siis tyystin irrottautua työelämän vaatimasta aviositeestä tietokoneeseen.

Muutama haastateltava mainitsi, että joutuessaan tekemään tietokoneella töitä kotona he saattavat samalla katsella televisiota sivusilmällä. Kotona mainittiin tehtävän vähemmän keskittymistä vaativia tehtäviä (esim. työsähköpostien lukeminen), joka mahdollisti samalla television sivusilmällä seuraamisen. Kun työtehtäviä tehdessä taustalla pyörii vaikkapa urheilukilpailut, voi televisio-ohjelman tulkita toimivan tässä resurssina, jonka avulla kodin ja työpaikan rajaa pidetään yllä. Television avulla voidaan tuottaa kotona tapahtuvista tekemisistä kokemuksellisesti erilaisia. Tarkoitus ei ole keskittyä intensiivisesti työtehtäviin, vaan saada nimenomaan vapaata siltä, että joutuisi keskittymään niihin juuri samalla tavalla kuin työpaikalla. (Peteri 2006, 316-318.)

Kontrolloitu subjektius korostuu siinä, miten haastateltavat tarkkailevat ja arvioivat itseään, työtätekevää minäänsä. Tämä näkyy muun muassa kuvailuissa, joissa kerrotaan, miten median avulla töistä väsynyttä minää osataan palkita ja "lepuuttaa". Tarkkaileva minä arvioi, mikä aktiviteetti missäkin tilanteessa parhaiten rentouttaa töistä väsyneen minän. Tämä tarkkaileva minä voi myös arvioida sitä, miten omia harrastuksia täytyy "hallita" siitä näkökulmasta etteivät ne ala muistuttaa liikaa työelämää. Sinänsä innostava harrastus voi alkaa muistuttaa työelämää, jos sen käytännöt muuttuvat liian suunnitelmallisiksi ja järjestäytyneiksi. Pariskunta, jonka molemmat osapuolet toimivat johtotehtävissä, kertoo vuosikymmeniä kestäneestä viiniharrastuksestaan:

Nainen: Jossain vaiheessa me tehtiin sillai, että me otettiin, me otettiin tuota noin etiketit irrotettiin ja etikettien taakse laitettiin informaatiota, mutta sit kävi, sitten nää ryökäleet rupes tekemään niin tuota..

Mies: Semmosia liimoja, ettei ne..

Haastattelija: Se on ihan totta. 
Nainen: Nyt ei oo enää jaksanu sillä tavalla oikeestaan, kun se, mun mielestä työelämässä on niin hemmetin systemaattista, niin mun mielestä vapaa-aikana pitää saada inspiroida ja mennä tän niinkun, how you feel.. (Haastattelu V7: Naisjohtaja ja miesjohtaja)

Viiniharrastukseensa pariskunta on kertonut hyödyntävänsä monipuolisesti erilaisia median muotoja. Ideoita ja informaatiota etsitään lehdistä, kirjoista, televisiosta sekä internetistä. Aiemmin pariskunta keräsi viinipullojen etikettejä ja päivitti leikekirjaa, johon etiketit kerättiin ja johon liitettiin yksityiskohtaisia kuvailuja kyseisestä viinistä ja sen nautintahetkestä. Sittemmin tämä puoli harrastuksesta oli hylätty ja yhtenä syynä haastateltava mainitsee sen, että harrastus oli alkanut systemaattisuudessaan muistuttaa jo liikaa työelämän velvoitteita. Harrastuksessa keskeistä haastateltavan mukaan on spontaanius, joka alkoi harrastusaineiston keräilyn myötä kärsiä.

Kotielämän merkitys rakentuu monin tavoin suhteessa ansiotyön merkitykseen. Pierre Bourdieuta (1998) mukaillen eri elämän sfäärien välillä vallitsee homologinen suhde. Kun siis teet tietynlaista työtä, se heijastuu myös vapaa-aikaasi. Korkeasti koulutetut pyrkivät harrastamaan vapaa-ajallaan "kultivoituneita", kehittäviä harrastuksia, jotka muistuttavat monin tavoin heidän ansiotyötehtäviään. Tämän voi ajatella näkyvän myös siinä, miten viikonlopun median seuraaminen voidaan kehystää kuvailuilla, jotka tekevät siitä jotenkin "syvällisempää" kuin arkinen television "töllöttäminen" ja kuvailuissa, joissa nimenomaan printtimedia toimii siirtymäriitin resurssina. Arkinenkin television töllöttäminen voidaan oikeuttaa sitä kautta, että silloin kertoja nollaa itseään vaativan ja vastuullisen työnsä paineista.

Toisaalta ansiotyön ja vapaa-ajan suhteiden tutkimuksessa on korostettu erityisesti elämänalueiden välistä rajanvetoa uudenlaisena modernin elämän haasteena, jota voisi itsessään jo verrata työhön. Kuten edellisestä aineistokatkelmastakin voi huomata, vapaa-aika ei voi olla ihan samanlaista kuin työelämä, jotta sitä voitaisiin pitää eriytyneenä elämänalueena.

\section{Media vapaa-ajan merkitsijänä}

Artikkelissa analysoitu aineisto kerättiin alkujaan Tampereen yliopiston sosiaalitutkimuksen laitoksen ja KCL:n yhteisprojektiin, jossa oltiin kiinnostuneita perheiden mediavalinnoista ja erityisesti siitä, mikä on printtimedian rooli arjen mediakentällä. Haastatteluissa kysyttiin myös tutkittavien työelämästä, koska sen arveltiin heijastuvan vapaaajan aktiviteetteihin. Jonkinmoinen yllätys oli kuitenkin se, että ihmiset tuottivat niin runsaasti spontaaneja kertomuksia ja kuvailuja siitä, miten erilaisten vapaa-ajan mediavalintojen takana olivat ansiotyötehtäviin liittyvät kokemukset; projektien tiukat määräajat, kotona työskentely ja väsymys sekä halu pitää kotielämä ja työn vaatimukset jollain tavalla erillään. Loppujen lopuksi syntyi vaikutelma, että juuri tämä oli haastatteluiden keskeisin teema.

Median ja ansiotöiden suhde näyttäytyy aineistossa kahtalaisena. Toisaalta erilaiset mediateknologiat toimivat linkkinä työ- ja kotielämän välillä. Tietokone, internet ja matkapuhelin mahdollistavat näiden elämänalueiden sekoittumisen. Samalla erilaiset 
median muodot toimivat resurssina rajanvedolle. Ne tarjoavat sisältöjä, joiden avulla arjen aktiviteetit voidaan kehystää lisäinformaatiolla, joka tuottaa niistä toimintana merkityksellisempää. Kyse ei vaikkapa ole enää vain pakollisesta ruoan laittamisesta, vaan periaatteessa sama toiminta voidaan tulkita provencelaisen illallisen valmistamisena. Viikonlopulle voidaan varata elokuvia, joita perustellaan sillä, että niitä yhdistää jokin teema tai ohjaaja. Tällöin kyse ei enää ole vain television töllöttämisestä, vaan valikoidun sisällön seuraamisesta, jolle on luotu jokin merkityksellisempi mieli. Projektiluontoinen työ vaatii projektiluontoisemman kotielämän, jonka tulee tarjota aitoja, syviä ja merkityksellisiä kokemuksia.

Vaikka työ- ja vapaa-ajan voi tulkita Bourdieun hengessä jossain määrin koostuvan toisiaan muistuttavista, merkityksellisistä elämän projekteista, aktiivista rajanvetoa näiden elämän alueiden välillä tuotetaan puheessa runsaasti. Esimerkiksi vapaa-ajan harrasteet eivät saa muuttua systemaattisiksi itsensä kehittämisen projekteiksi. Aineistossa erilaisten median muotojen avulla kuvaillaan merkattavan tiettyjä kotielämän hetkiä selkeiksi siirtymiksi, jonka jälkeen on latauduttu työelämän roolista kotielämän rooliin. Siirtymäriitin hengen mukaisesti kerrotaan, miten näitä siirtymiä varten valmistetaan oma paikkansa, välipalansa ja pukeutumisensa, joka vahvistaa hetken merkitystä siirtymänä. Paradoksaalisesti kotielämän "puhtauden" ylläpitäminen vaatii siis touhukasta rajanvetotyötä.

Diskurssianalyyttisestä näkökulmasta katsottuna en voi suoraan väittää, että ihmiset tietoisesti valmistavat median avulla "siirtymäriitin" tai tulkitsevat toimintaansa juuri van Gennepin hengessä siirtymäriittinä. Puhe siirtymäriitistä tai selviytymisstrategiasta on tutkijan käsitteellistys ja tulkinta kuvatusta toiminnasta. Sen sijaan voin väittää, että haastateltavien kuvailuilla ja kertomuksilla omasta vapaa-ajan median käytöstään on seurauksensa: kuvaamalla median käyttöään edellisin tavoin, he tuottavat erityisen vapaa-ajan median ja vapaa-ajan median seuraamisen, joka merkitsee omalta osaltaan vapaa-ajan juuri vapaa-ajaksi. Täten haastateltavien kuvauksien voi tulkita tuottavan todellisuuden, jossa tietyssä kontekstissa median avulla tuotetaan siirtymiä tai media tuotetaan selviytymiskeinoina. Tähän diskursiiviseen saavutukseen haastateltavat hyödynsivät useita kielellisiä keinoja. Yksi kielellinen keino on kontekstin tarkka kuvaaminen, kun kyseessä on vapaa-ajan aloittava median käyttö. Toinen tapa on tuottaa viikonlopun median käyttö selkeänä ja tietoisena valintaprosessina, joka voi vaatia runsaasti erityistä valmistelutyötä. Kolmanneksi vähemmän kehittävä vapaa-ajan median seuraaminen oikeutetaan liittämällä se mielikuvaan vaativasta ja vastuullisesta työstä ja itseään tarkkailevasta kertojasta.

Mediavalintoja, erityisesti arkiviikon television katseluun liittyviä, kuvaillaan väsymyksestä selviytymisen välineinä. Tällöin kyse ei samalla tavalla ole selvästi merkitystä siirtymästä, vaan arjen välttämättömyydestä, hengähdystauosta. Nämä kertomukset mediavalinnoista siis rakennettiin mielentilakuvauksien ympärille. Samalla television katselulle luodaan ylevämpi perustelu. Katselija ei ainoastaan passiivisesti nauti amerikkalaisesta tv-viihteestä, vaan pyrkii palautumaan raskaasta ja vaativasta työstään. Lukemiskuvausten ja television katselun kuvausten erilaisuutta voi havainnollistaa konkreettisella esimerkillä, jossa eräs haastateltava mainitsi töistä kotiin saapuessaan riisuvansa kengät ja päällysvaatteet vasta aukaistuaan television, joka jätettiin taus- 
talle pyörimään. Maininta eroaa selkeästi kertomuksista, joissa lehden lukemiselle huolella valmisteltiin oma erityinen hetkensä.

Tutkittavien työelämäkertomuksille leimallista on ns. tarkkailevan minän position rakentaminen. Ahkera työminä vaatii vastapainokseen tarkkailevan minän, jonka on opeteltava palkitsemaan ja lepuuttamaan työminäänsä. Työminää pitää osata tarkkailla, jotta kykenee tunnistamaan, milloin työminä käy liian väsyneeksi ja tehottomaksi. Näissä kuvailuissa näkyy yhtäaikaisesti hallinnoitu, työn puristuksessa oleva minä ja refleksiivinen, joustavaa työtä tekevä tarkkailija, joka arvioi (näennäisen) itsenäisesti, koska on aika ottaa vapaata.

\section{Kirjallisuus}

Ashforth, Blake E., Kreiner, Glen E. \& Fugate, Mel (2000). All in a Day's Work: Boundaries and Micro Role Transitions. The Academy of Management Review 25:3, 472-491.

Brannen, Julia (2005). Time and Negotiation of Work-Family Boundaries. Autonomy or Illusion? Time Q Society 14:1, 113-131.

Berke, Debra L. (2003). Coming Home Again. The Challenges and Rewards of Home-Based SelfEmployment. Journal of Family Issues 24:4, 513-546.

Bourdieu, Pierre (1998). Distinction. A Social Critique of the Judgement of Taste. Cambridge, Massachusetts: Harvard University Press.

Burr, Vivien (1995). An Introduction to Social Constructionism. London: Routledge.

Campbell, Colin (2005). The Craft Consumer: Culture, Craft and Consumption in a Postmodern Society. Journal of Consumer Culture 5:1, March, 23-42.

Desrochers, Stephan, Hilton, Jeanne \& Larwood, Laurie (2005). Preliminary Validation of the WorkFamily Integration-Blurring Scale. Journal of Family Issues 26:4, 442-466.

van Gennep, Charles A. (1960). The Rites of Passage. Chicago: University of Chicago Press.

Eyre, Stephen L., Davis, Eric W. \& Peacock, Ben (2001). Moral argumentation in adolescents' commentaries about sex. Culture, Health Q Sexuality no. 1, vol. 3, 1-17.

Jolanki, Outi (2004). Moral argumentation in talk about health and old age. Health: An Interdisciplinary Journal for the Social Study of Health, Illness and Medicine no. 4 vol. 8, 483-503.

Julkunen, Raija, Nätti, Jouko \& Anttila, Timo (2004). Aikanyrjähdys. Keskiluokka työn puristuksessa. Tampere: Vastapaino.

Katz-Gerro, Tally (2002). Highbrow Cultural Consumption and Class Distinction in Italy, Israel, West Germany, Sweden and the United States. Social Forces vol. 81, no. 1, 207-229.

Kivimäki, Riikka (1999). "Työ on mielentila". Miten arki muuttuu, kun työ ei riipu ajasta ja paikasta? Teoksessa: Eriksson, Päivi \& Vehviläinen, Marja (toim.) Tietoyhteiskunta seisakkeella. SoPhi: Jyväskylän yliopisto, 150-168.

Kaufman-Scarborough, Carol (2006). Time Use and the Impact of Technology. Examining workspaces in the home. Time Q Society 15:1, 57-80.

Kumar, Krishan (1997). Home: The Promise and Predicament of Private Life at the End of the Twentieth Century. Teoksessa: Weintraub, Jeff. \& Kumar, Krishnan (toim.) Public and Private in Thought and Practice. Perspectives on a Grand Dichotomy. Chicago: University of Chicago Press, 204-236.

Livingstone, Sonja (2002). Young People and New Media. London: Sage

Luomanen, Jari (tulossa 2010). Accounting for Media Use: The Moralities of Information and Communication Technology. Tampere: Tampere University Press.

McDowell, Linda (1999). Gender, Identity Q Place. Understanding Feminist Geographies. Cambridge: Polity Press.

Moores, Shaun (1996). Satellite Television and Everyday Life. Articulating Technology. Luton: University of Luton Press. 
Nikander, Pirjo (2002). Age in Action. Membership Work and Stage of Life Categories in Talk. Helsinki: Academia Scientiarum Fennica. The Finnish Academy of Science and Letters.

Nippert-Eng, Christina (1996). Home and Work. Negotiating Boundaries through Everyday Life. Chicago: The University of Chicago Press.

Parkins, Wendy (2004). Out of Time. Fast Subjects and Slow Living. Time Q Society 13:2/3, 363-382.

Peteri, Virve (2005). Ansiotyötä kotiuttamassa - Asumisen erikoislehdet ja ansiotyön uudet paikat. Työelämän tutkimus 1, 1-11.

Peteri, Virve (2006). Mediaksi kotiin. Tutkimus teknologioiden kotouttamisesta. Tampere: Tampere University Press.

Potter, Jonathan \& Wetherell, Margaret (1989). Discourse and Social Psychology. London: Sage.

Potter, Jonathan (2004). Discourse analysis as a way of analysing naturally occurring talk. Teoksessa Silverman, David (toim.) Qualitative Research: Theory, method and practice, London: Sage, 200221.

Punie, Yves, Bogdanowicz, Marc, Berg, Anne-Jorunn, Pauwels, Caroline \& Burgelman, Jean-Claude (2005). Consumption and Quality of Life in a Digital World. Teoksessa Silverstone Roger (toim.) Media, Technology and Everyday Life in Europe. From Information to Communication. Aldershot: Ashgate, 93-106.

Ronkainen, Suvi (2004). Kvantitatiivisuus, tulkinnallisuus ja feministinen tietäminen. Teoksessa Liljeström, Marianne (toim.) Feministinen tietäminen. Keskustelua metodologiasta. Tampere: Vastapaino, 44-69.

Rose, Nikolas (1999). Governing the Soul. The Shaping of the Private Self. London: Routledge.

Rybczynski, Witold (1986). Home. A Short History of an Idea. New York: Penguin Books.

Saarenheimo, Marja (1997). Jos etsit kadonnutta aikaa. Vanhuus ja oman elämän muisteleminen. Tampere: Vastapaino.

Salmi, Minna (1991). Ansiotyö kotona - toiveuni vai painajainen? Kotiansiotyö Suomessa työntekijän arkipäivän kannalta. Helsinki: Yliopistopaino.

Sending, Ole Jacob \& Neuman, Iver B. (2006). Governance to Govermentality: Analyzing NGOs, States, and Power. International Studies Quaterly 50:3, 651-672.

Siltala, Juha (2004). Työelämän huonontumisen lyhyt historia. Helsinki: Otava

Silverstone, Roger (1993). Time, Information and Communication Technologies and the Household. Time Q Society 2:3, 283-311.

Silverstone, Roger (2005) Introduction. Teoksessa Silverstone Roger (toim.) Media, Technology and Everyday Life in Europe. From Information to Communication. Aldershot: Ashgate, 1-20.

Southerton, Dale \& Tomlinson, Mark (2005). 'Pressed for time'- the differential impacts of a 'time squeeze' The Sociological Review 53:2, 215-239.

Sullivan, Oriel (2008). Busyness, Status Distinction and Consumption Strategies of the Income Rich, Time Poor. Time Q Society 17:1, 5-26.

Suoninen, Eero (1992). Perheen kuvakulmat: Diskurssianalyysi perheenäidin puheesta. Tampereen yliopisto. Sosiologian ja sosiaalipsykologian laitos. Tutkimuksia sarja A, no.24.

Wetherell, Margaret \& Maybin, Janet (1996). The Distributed Self: A Social Constructionist Perspective. Teoksessa Stevens, Richard (toim.) Understanding the Self. London: Sage, 219-279. 